\title{
Systematic Literature Review Analisis Metode Agile dalam Pengembangan Aplikasi Mobile
}

\author{
Azizah Nurfauziah Yusril, Inggrit Larasati*, Pajri Al Zukri \\ Sistem Informasi, Fakultas Sains dan Teknologi, UIN Syarif Hidayatullah Jakarta, \\ Jl. Ir H. Juanda No.95, Cemp. Putih, Kec. Ciputat, Kota Tangerang Selatan, Banten 15412 \\ *Email: inggrit.larasati17@mhs.uinjkt.ac.id
}

(received: 16 Januari 2021, revised: 25 Maret 2021, accepted: 17 April 2021)

\begin{abstract}
ABSTRAK
Aplikasi secara umum dibagi menjadi 3 platform yaitu desktop, web, dan mobile. Aplikasi mobile adalah teknologi yang paling banyak digunakan, hal ini didukung dengan perkembangan smartphone yang semakin canggih. Pengembangan aplikasi berbasis mobile memiliki banyak metode yang bisa digunakan, salah satunya adalah metode agile. Metode ini merupakan salah satu metode yang terkenal karena dianggap aktual dan mudah digunakan. Penelitian ini menggunakan metode systematic literature review yang menampilkan analisis metode agile dalam pengembangan aplikasi berbasis mobile yang mencakup total X makalah yang diterbitkan dari tahun 2015 hingga 2020. Penelitian ini bertujuan untuk menjawab beberapa pertanyaan penelitian yaitu: 1) Mengetahui tren model apa saja yang digunakan dalam metode agile, 2) Mengetahui bidang apa saja yang mengimplementasikan metode agile dalam pengembangan aplikasi berbasis mobile. Berdasarkan hasil review dari 44 literatur, dengan manjawab research question yang ada, model metode agile yang paling sering digunakan dengan presentase $41 \%$ adalah XP (Extreme Programming), selanjutnya fokus bidang yang paling banyak dijadikan tema penelitian dengan persentase $23 \%$ adalah pada bidang produktivitas.
\end{abstract}

Kata Kunci: Aplikasi Mobile, Literatur Review, Metode Agile.

\begin{abstract}
Applications are generally divided into 3 platforms, namely desktop, web and mobile. Mobile applications are the most widely used technology, supported by increasingly sophisticated smartphone developments. Mobile-based application development has many methods that can be used, one of which is the agile method. This method is one of the well-known methods because it is considered up-to-date and easy to use. This study uses a systematic literature review method which displays agile method analysis in mobile-based application development which includes a total of $X$ papers published from 2015 to 2020. This study aims to answer several research questions, namely: 1) Knowing the trends of the models used in the research. agile methods, 2) Knowing what fields implement agile methods in developing mobile-based applications. Based on the results of a review of 44 literatures, by answering existing research questions, the agile method models most often used with a percentage of $41 \%$ is XP (Extreme Programming), then the focus of the field that is most used as a research theme with a percentage of $23 \%$ is in the field of productivity.
\end{abstract}

Keywords: Mobile Application, Literature Review, Agile Methodology.

\section{Pendahuluan}

Systematic literature review adalah sarana untuk mengidentifikasi, menilai, dan menjelaskan semua penelitian yang berkaitan dengan pertanyaan penelitian tertentu, bidang topik, atau fenomena yang menarik [1]. Dalam melakukan kajian, pemahaman suatu penelitian secara komprehensif merupakan salah satu syarat yang harus dipenuhi oleh peneliti. Systematic Literature Review merupakan metode yang berhubungan dengan tinjauan pustaka yang berkaitan dengan pertanyaan yang harus dijawab oleh peneliti. Hal tersebut dilakukan secara realistis dengan mengidentifikasi, menyeleksi, dan menilai literatur penelitian yang relevan yang menjadi fokus pembahasan [2]. 
Metode agile dipilih sebagai objek dalam penelitian ini karena metode agile merupakan salah satu metode yang cukup popular saat ini karena menawarkan fleksibilitas, sehingga pengembang bisa kembali ke fase yang lebih awal apabila ada perubahan yang diperlukan [3]. Metode agile adalah salah satu metodologi pengembangan perangkat lunak yang efektif dan tangkas. Metode ini tidak mendefinisikan prosedur secara detail untuk bagaimana membuat tipe model yang telah diberikan, meskipun terdapat cara untuk menjadi suatu modeler yang efektif [4]. Pendekatan agile untuk pengembangan mobile aplikasi menyatakan pendekatan iteratif dan inkremental yang terdiri dari tim yang mengatur dirinya sendiri dan tim yang bekerja sama untuk membangun perangkat lunak [5].

Penyebaran dan penggunaan aplikasi mobile telah meledak sejak peluncuran iPhone oleh Apple dan sistem operasi Android oleh Google [6]. Indonesia menempati urutan ke empat dalam pengguna smartphone di dunia. China, India, Amerika Serikat menempati urutan pertama, kedua dan ketiga secara berurutan. Dengan total populasi 273.524.000, Indonesia memiliki pengguna smartphone sebanyak 158,667,000 atau bisa dikatakan terjadi 58,01\% penetrasi smartphone di Indonesia.

Aplikasi mobile saat ini berkembang sangat pesat, selama 5 tahun terakhir jumlah aplikasi di dalam Apple Store meningkat setiap tahunnya, pada tahun 2018 terjadi peningkatan aplikasi nongame yang signifikan dan peningkatan aplikasi game yang signifikan terjadi pada tahun 2015 . Sedangkan jumlah aplikasi di GooglePlay mengalami peningkatan yang signifikan di tahun 2016, kemudian terjadi penurunan sebanyak 25\% di tahun 2018 - 2019, hal ini dikarenakan Google harus menyortir mobileapp karena terindikasi malware. Hal ini menandakan bahwa Google mengerti adanya peningkatan permintaan terhadap mobileapp. Sehingga Google memastikan user android aman dari ancaman malware.

Penelitian ini menampilkan sebuah tinjauan literatur sistematis dari analisis metode agile dalam pengembangan aplikasi berbasis mobile yang mencakup total $\mathrm{X}$ makalah yang diterbitkan dari tahun 2015 hingga 2020. Penelitian ini bertujuan untuk menjawab beberapa pertanyaan penelitian yaitu: 1) Mengetahui tren model apa saja yang digunakan dalam metode agile, 2) Mengetahui bidang apa saja yang mengimplementasikan metode agile dalam pengembangan aplikasi berbasis mobile.

\section{Tinjauan Literatur}

Penelitian sebelumnya dilakukan oleh [7], [8], [9], [10], [11] telah mendiskusikan penggunaan agile. Perbedaan penelitian sebelumnya dengan penelitian ini, penelitian sebelumnya tidak membahasa secara detail mengenai agile dalam pengembangan aplikasi mobile khususnya tren model metode jenis agile yang digunakan dalam pengembangan aplikasi berbasis mobile dan jenis aplikasi berbasis mobile apa yang menggunakan metode agile. Agile adalah salah satu metodologi dalam tahap pengembangan sebuah perangkat lunak yang efektif [4]. Agile dikatakan pula sebagai pendekatan pengembangan sistem yang menitikberatkan pada kecepatan delivery dan memungkinkan perubahan setiap saat [12].

Berikut ini beberapa model dalam metode agile yaitu:

a. Extreme Programming (XP)

$\mathrm{XP}$ adalah pengembangan software yang memiliki sasaran yaitu pembangunan melalui penetapan kebutuhan yang kurang jelas atau adanya perubahan terhadap kebutuhan yang sangat cepat dan melalui tim yang berskala kecil sampai menengah [13].

b. SCRUM

SCRUM adalah model yang mengedepan kecepatan pengembangan. Dalam proses scrum, rencana proyek terus diperiksa dan disesuaikan berdasarkan kenyataan empiris proyek [14].

c. Spiral Model

Spiral model lebih menenakankan pada analisa resiko [15]. Spiral model memiliki empat fase proses yaitu planning, risk analysis, engineering dan evaluation.

d. Rapid Application Development (RAD)

RAD didasari proses prototype dan iterative dengan tidak memiliki rencana spesifik untuk tahap selanjutnya. Proses pembuatan kode menjadi dasar dari penentuan rencana spesifik selanjutnya. Prototype rapid mengerjakan aspek fungsional sebagai subset dari prodak secara keseluruhan [16].

e. Mobile-D 
Mobile-D merupakan model yang khusus dirancang untuk pengembangan aplikasi mobile yang didasarkan pada praktek agile [17]. Mobile-D terdapat lima tahapan, yaitu explore, initialize, productionize, stabilize, dan system test and fix.

Ada banyak kategori aplikasi di dalam Playstore. Kategori tersebut dibagi menjadi berbagai macam yaitu: seni \& desain, otomotif \& kendaraan, kecantikan, buku \& referensi, bisnis, komik, komunikasi, kencan, pendidikan, hiburan, acara, keuangan, makanan \& minuman, kesehatan \& kebugaran, griya \& rumah, pustaka \& demo, gaya hidup, peta \& navigasi, kedokteran, musik \& audio, berita \& majalah, mengasuh anak, personalisasi, fotografi, produktivitas, belanja, sosial, olahraga, alat, perjalanan \& lokal, pemutar \& editor video, cuaca. Kategori ini dibuat untuk membantu pengguna menelusuri dan menemukan aplikasi yang relevan di PlayStore [18].

\section{Metodologi Penelitian}

Metode Systematic Literature Review (SLR) yang digunakan peneliti berdasarkan pedoman [19]. SLR adalah cara penelitian untuk melakukan tinjauan pustaka dengan cara yang teratur memetakan fase-fase tertentu. Pada Gambar 1, metode SLR menggunakan tiga fase untuk melakukan tinjauan pustaka yaitu merencanakan dan menentukan pertanyaan penelitian, melakukan tinjauan yang terdiri dari identifikasi pencarian string dan sumber data, pemilihan studi, penilaian kualitas, dan ekstraksi data dan akhirnya pelaporan tinjauan.

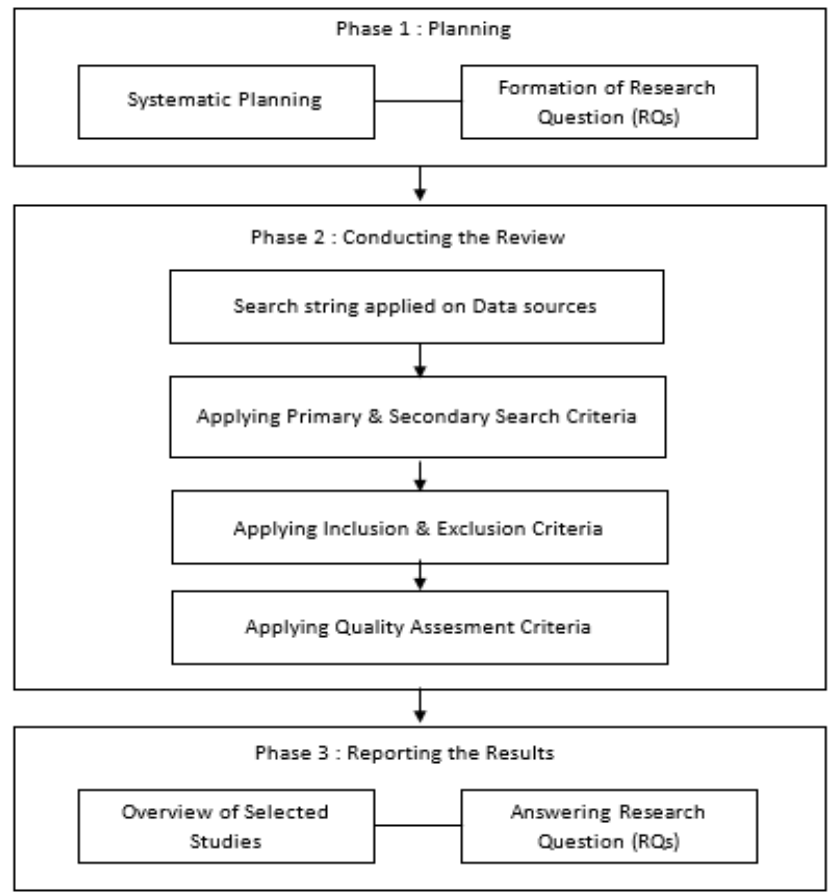

Gambar 1. Systematic Literature Review Phase [19].

\section{Planning Phase}

Untuk kelancaran tinjauan pustaka yang sistematis, perencanaan yang tepat sangat penting untuk kelancaran pelaksanaan SLR. Pertanyaan penelitian berasal dari seluruh tahap perencanaan tinjauan literatur sistematis.

a. Research Question

Penelitian ini bertujuan untuk menjawab beberapa pertanyaan penelitian yaitu:

RQ1: Mengetahui tren model apa saja yang digunakan dalam metode agile?

RQ2: Mengetahui bidang apa saja yang mengimplementasikan metode agile dalam pengembangan aplikasi berbasis mobile? 
2. Conducting the review phase

a. Search Strategy

Maksud dari strategi pencarian adalah untuk menemukan studi-studi yang akan membantu dalam menjawab RQ. Tiga fase dari strategi pencarian terdiri dari:

1). Identifying keywords and defining search string

Kata Kunci yang digunakan dalam pencarian literatur pada penelitian ini adalah pembuatan aplikasi mobile dengan menggunakan metode agile.

\section{2). Data Sources}

Data literatur dalam penelitian ini bersumber dari "GoogleScholar" yang diterbitkan dari tahun 2015 hingga 2020.

3). Search Process in Data Sources

Pada proses ini mencari literatur yang sesuai dengan keyword yang telah ditentukan di dalam sumber data, dimana menghasilkan total 709 artikel yang dikunjungi pada tanggal 30 November 2020.

b. Inclusion/Exclusion Criteria for Selecting Studies

Hasil yang diperoleh dari string pencarian yang ditentukan sebelumnya dalam sumber data dianalisis sesuai dengan kriteria inklusi / eksklusi seperti terlihat pada Tael 1. Evaluasi makalah dilakukan dengan membaca judul dan abstrak terlebih dahulu dan dicek apakah ada kaitannya dengan isu-isu yang dibahas dalam RQ.

Tabel 1. Kriteria Inklusi dan Eksklusi

\begin{tabular}{|l|l|}
\hline \multicolumn{1}{|c|}{ Kriteria Inklusi } & \multicolumn{1}{c|}{ Kriteria Eksklusi } \\
\hline $\begin{array}{l}\text { Literatur yang berfokus padapembuatan aplikasi } \\
\text { mobile menggunakan metode agile }\end{array}$ & $\begin{array}{l}\text { Literatur yang tidak berfokus padapembuatan } \\
\text { aplikasi mobile menggunakan metode agile }\end{array}$ \\
\hline $\begin{array}{l}\text { Literatur menjawab setidaknya satu pertanyaan } \\
\text { penelitian }\end{array}$ & Literatur tidak menjawab pertanyaan penelitian \\
\hline $\begin{array}{l}\text { Literatur menggunakan Bahasa Indonesia dan } \\
\text { Bahasa inggris }\end{array}$ & $\begin{array}{l}\text { Studi tidak dipublikasikan dalam Bahasa Inggris / } \\
\text { Bahasa Indonesia }\end{array}$ \\
\hline
\end{tabular}

c. Quality Assessment

Setelah menerapkan kriteria inklusi dan eksklusi, penilaian kualitas untuk setiap studi dipastikan. Penilaian kualitas dicapai dengan membagikan skor untuk studi yang dipilih. Lima pertanyaan penilaian disiapkan yang dapat dijawab dengan skor 1 (ya), 0,5 (parsial) atau 0 (tidak). Pertanyaannya tercantum di bawah ini:

Q1. Apakah tujuan penelitian dinyatakan dengan jelas?

Q2. Apakah metode agile didefinisikan dengan jelas?

Q3. Apakah pengembangan aplikasi berbasis mobile?

d. Data Extraction

Fase ekstraksi data melibatkan ekstraksi data dari studi terpilih akhir yang membahas kekhasan RQ. Informasi berikut dikumpulkan dalam bentuk ekstraksi data:

- Judul studi yang dipilih

- Penulis

- Tahun

- Jenis sumber data elektronik

- Sumber publikasi

- Jenis studi

- Temuan utama dalam studi (karakteristik / metode / alat pendukung)

- RQ dialamatkan.

3. Reporting The Result

a. Select Studies Overview

Menunjukkan distribusi literatur yang dipilih melalui sumber yang diterbitkan. Dari 709 literatur kemudian difilter berdasarkan mobile dan metode agile menghasilkan 91 
literatur, selanjutnya difilter kembali menjadi 44 literatur yang sesuai dengan Quality Assesment, seperti pada Gambar 2 dan Tabel 2.

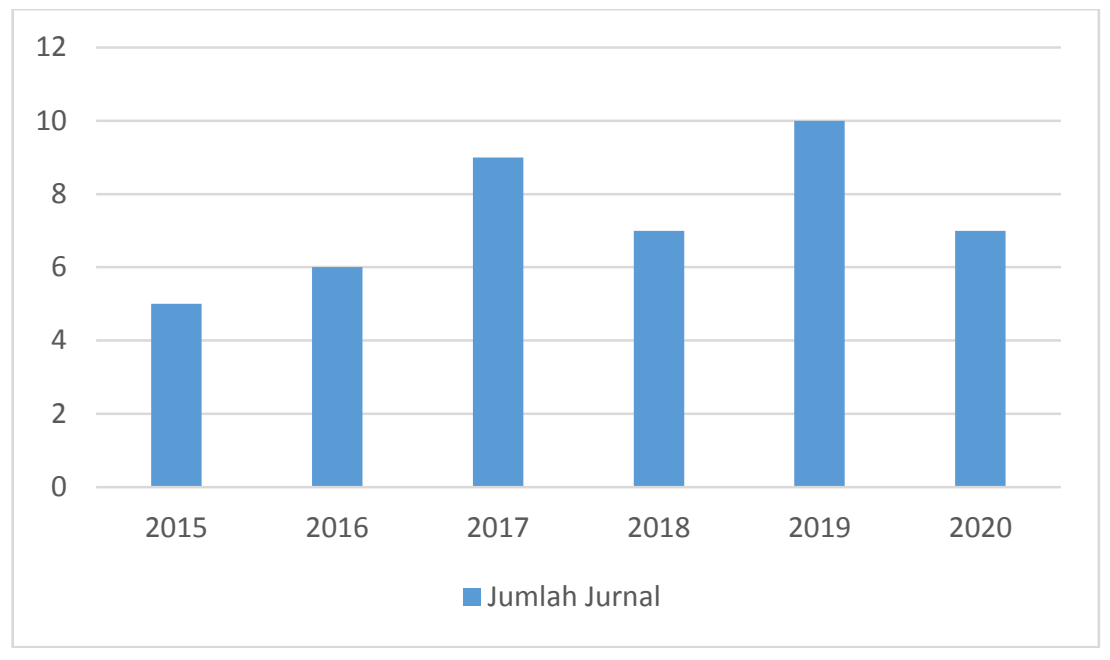

Gambar 2. Select Studies Overview

Tabel 2. Deskripsi Select Studies Overview

\begin{tabular}{|c|c|c|c|c|c|}
\hline No & $\begin{array}{l}\text { Jurnal/ } \\
\text { Prosiding }\end{array}$ & Judul Jurnal & $\begin{array}{l}\text { Model } \\
\text { Agile }\end{array}$ & Bidang & Tahun \\
\hline 1 & Jurnal & $\begin{array}{l}\text { Membangun Mobile Game Sebagai Assistive } \\
\text { Technology untuk Membantu } \\
\text { Mengembangkan Social Interaction Skill } \\
\text { Pada Penderita Attention Deficit } \\
\text { Hyperactivity Disorder (ADHD) } \\
\text { Menggunakan Metode Agile Development } \\
{[20] \text {. }}\end{array}$ & $\mathrm{AM}$ & Game & 2015 \\
\hline 2 & Jurnal & $\begin{array}{l}\text { Aplikasi ISC (Informatics Student Center) } \\
\text { Menggunakan Metode Personal Extreme } \\
\text { Programming Berbasis Android [21]. }\end{array}$ & $\mathrm{XP}$ & Pendidikan & 2015 \\
\hline 3 & Jurnal & $\begin{array}{l}\text { Perancangan Dashboard Sistem Informasi } \\
\text { untuk Agile Manajemen Proyek dengan } \\
\text { Menggunakan JIRA - Studi Kasus di PT. } \\
\text { Flashiz Indonesia [22]. }\end{array}$ & SCRUM & Produktivitas & 2015 \\
\hline 4 & Jurnal & $\begin{array}{l}\text { Penerapan Algoritma Floyd Warshall dalam } \\
\text { Pencarian Rute Terpendek dan Tercepat Pada } \\
\text { Studi Kasus di Singapura hingga Thailand } \\
\text { Selatan Berbasis Android [23]. }\end{array}$ & OOAD & $\begin{array}{l}\text { Peta } \\
\text { Navigasi }\end{array}$ & 2015 \\
\hline 5 & Jurnal & $\begin{array}{l}\text { Pemanfaatan Mac Address Hotspot dalam } \\
\text { Pengembangan Sistem Absensi GPS dalam } \\
\text { Rangka Meningkatkan Keakuratan Posisi } \\
\text { Pengguna [24]. }\end{array}$ & XP & $\begin{array}{l}\text { Peta } \\
\text { Navigasi }\end{array}$ & 2015 \\
\hline 6 & Jurnal & $\begin{array}{l}\text { Pengembangan Sistem Manajemen Presensi } \\
\text { Rapat Berbasis QR Code Pada Android [25]. }\end{array}$ & Scrum & Produktivitas & 2016 \\
\hline 7 & Jurnal & $\begin{array}{l}\text { Pengembangan Game "Super Sonic Shoot" } \\
\text { Dengan Pendekatan Game-Scrum [26]. }\end{array}$ & Scrum & Game & 2016 \\
\hline 8 & Jurnal & $\begin{array}{l}\text { Rancang Bangun Aplikasi Fasilitas Umum } \\
\text { Berbasis Web Services [27] }\end{array}$ & DAD & $\begin{array}{l}\text { Perjalanan \& } \\
\text { Lokal }\end{array}$ & 2016 \\
\hline 9 & Jurnal & 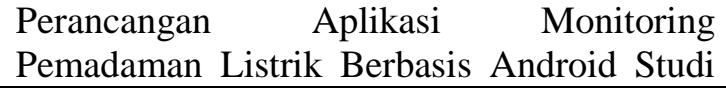 & DAD & Produktivitas & 2016 \\
\hline
\end{tabular}




\begin{tabular}{|c|c|c|c|c|c|}
\hline & & Kasus PT.PLN Area Manado [28] & & & \\
\hline 10 & Jurnal & $\begin{array}{l}\text { Pengembangan Fungsi } \text { Pengajuan Cuti } \\
\text { Karyawan Pada Sistem Absensi Mobile [29] }\end{array}$ & $\mathrm{XP}$ & Produktivitas & 2016 \\
\hline 11 & Jurnal & $\begin{array}{l}\text { Sistem Pakar Diagnosa Penyakit Anak } \\
\text { Menggunakan Metode Forward Chaining } \\
\text { Berbasis Mobile [30] }\end{array}$ & $\mathrm{XP}$ & Kedokteran & 2016 \\
\hline 12 & Prosiding & $\begin{array}{lll}\text { Aplikasi Pembelajaran Sejarah } & \text { Filsafat } \\
\text { Berbasis Android Menggunakan } & \text { Metode } \\
\text { Pengembangan Agile [31] } & & \end{array}$ & RUP & Pendidikan & 2017 \\
\hline 13 & Jurnal & $\begin{array}{l}\text { Mobile Application Monitoring Pengisian } \\
\text { Uang Anjungan Tunai Mandiri Pt Bank } \\
\text { Mandiri Cabang Palembang [32] }\end{array}$ & $\begin{array}{l}\text { Mobile } \\
\text { D }\end{array}$ & Produktivitas & 2017 \\
\hline 14 & Jurnal & $\begin{array}{l}\text { Rancang Bangun Game Edukasi Anak Usia } \\
\text { Dini Menggunakan Metode Extreme } \\
\text { Programming Berbasis Android [33] }\end{array}$ & $\mathrm{XP}$ & Game & 2017 \\
\hline 15 & Jurnal & $\begin{array}{l}\text { Pemanfaatan Jquery Mobile Untuk } \\
\text { Merancang Aplikasi Kinerja Salesman [34] }\end{array}$ & $\mathrm{XP}$ & Produktivitas & 2017 \\
\hline 16 & Jurnal & $\begin{array}{l}\text { Rekayasa Perangkat Lunak Berbasis Android } \\
\text { Sebagai Media Informasi Akademik Siswa } \\
\text { SMK PKP } 2 \text { Jakarta [35] }\end{array}$ & $\mathrm{XP}$ & Pendidikan & 2017 \\
\hline 17 & Jurnal & $\begin{array}{l}\text { Perancangan Aplikasi Navigasi Peta dengan } \\
\text { Pengenalan Suara Menggunakan Pendekatan } \\
\text { Agile Process dengan Model Extreme } \\
\text { Programming Berbasis Android [36] }\end{array}$ & $\mathrm{XP}$ & $\begin{array}{l}\text { Peta } \quad \& \\
\text { Navigasi }\end{array}$ & 2017 \\
\hline 18 & Jurnal & $\begin{array}{l}\text { Pemanfaatan Analytical Hierarchy Process } \\
\text { (AHP) Pada E-Voting Pemilihan Ketua Osis } \\
\text { [37] }\end{array}$ & $\mathrm{XP}$ & Produktivitas & 2017 \\
\hline 19 & Jurnal & $\begin{array}{l}\text { Sistem Pakar Diagnosa Autisme Pada Balita } \\
\text { Berbasis Android [38] }\end{array}$ & $\mathrm{XP}$ & Kedokteran & 2017 \\
\hline 20 & Jurnal & $\begin{array}{l}\text { Rancang Bangun Aplikasi Game Augmented } \\
\text { Reality Permainan Tradisional Sulawesi } \\
\text { Utara Dodorobe [39] }\end{array}$ & $\mathrm{XP}$ & Game & 2017 \\
\hline 21 & Jurnal & $\begin{array}{l}\text { Aplikasi Informasi Kesehatan dan Diagnosa } \\
\text { Penyakit Jantung Berbasis Android [40]. }\end{array}$ & XP & Kedokteran & 2018 \\
\hline 22 & Prosiding & $\begin{array}{l}\text { Pengembangan Aplikasi Android Berbasis } \\
\text { Teknologi Cloud Computing dan QR Code } \\
\text { untuk Pendataan Bus dan Penumpang di } \\
\text { Terminal Tipe-A Tamanan Kota Kediri [41] }\end{array}$ & $\mathrm{AM}$ & Produktivitas & 2018 \\
\hline 23 & Jurnal & $\begin{array}{l}\text { Pembangunan Sistem Informasi Zona Potensi } \\
\text { Sumber Daya Kelautan Kabupaten } \\
\text { Gunungkidul Berbasis HMVC Menggunakan } \\
\text { Google Maps API dan JSON [42] }\end{array}$ & $\mathrm{AM}$ & $\begin{array}{l}\text { Peta } \\
\text { Navigasi }\end{array}$ & 2018 \\
\hline 24 & Jurnal & $\begin{array}{l}\text { Pembangunan Sistem Aplikasi Hanasu: } \\
\text { Pembelajaran Bahasa Jepang Android Mobile } \\
\text { Memanfaatkan Google Speech Recognition } \\
\text { Library [43] }\end{array}$ & SCRUM & Pendidikan & 2018 \\
\hline 25 & Jurnal & $\begin{array}{l}\text { Pengembangan Aplikasi Mobile Augmented } \\
\text { Reality untuk Mendukung Pengenalan } \\
\text { Koleksi Museum [44] }\end{array}$ & $\mathrm{AM}$ & $\begin{array}{l}\text { Perjalanan dan } \\
\text { Lokal }\end{array}$ & 2018 \\
\hline 26 & Jurnal & $\begin{array}{l}\text { Rancang Bangun Aplikasi Pencarian Rumah } \\
\text { Ibadah di Kotamobagu Berbasis Android } \\
\text { [45] }\end{array}$ & DAD & $\begin{array}{l}\text { Peta } \\
\text { Navigasi }\end{array}$ & 2018 \\
\hline 27 & Jurnal & Aplikasi Self Service Menu Menggunakan & SCRUM & Bisnis & 2018 \\
\hline
\end{tabular}




\begin{tabular}{|c|c|c|c|c|c|}
\hline & & $\begin{array}{l}\text { Metode Scrum Berbasis Android (Case Study } \\
\text { : Warkobar Café Cikarang) [46] }\end{array}$ & & & \\
\hline 28 & Jurnal & $\begin{array}{l}\text { Membangun Aplikasi Pariwisata Berbasis } \\
\text { Android di Belitung [47] }\end{array}$ & $\mathrm{AM}$ & $\begin{array}{l}\text { Perjalanan \& } \\
\text { Lokal }\end{array}$ & 2019 \\
\hline 29 & Jurnal & $\begin{array}{l}\text { Integrasi Micro-Apps Individual Menjadi } \\
\text { One-Stop Services: Application Suite [48] }\end{array}$ & $\mathrm{AM}$ & Pendidikan & 2019 \\
\hline 30 & Jurnal & $\begin{array}{l}\text { Rancang Bangun Media Pembelajaran } \\
\text { Bahasa Arab untuk Anak Usia Dini Berbasis } \\
\text { Android [3] }\end{array}$ & $\mathrm{AM}$ & Pendidikan & 2019 \\
\hline 31 & Jurnal & $\begin{array}{l}\text { Pengembangan Aplikasi Mobile Manajemen } \\
\text { Keuangan dengan Metode Scrum (Studi } \\
\text { Kasus Mahasiswa Filkom UB) [14] }\end{array}$ & SCRUM & Keuangan & 2019 \\
\hline 32 & Jurnal & $\begin{array}{l}\text { Pengembangan Aplikasi Sportyway: Aplikasi } \\
\text { Pencari Teman Untuk Berolahraga Bersama } \\
\text { Berbasis Lokasi [49] }\end{array}$ & SCRUM & $\begin{array}{l}\text { Kesehatan \& } \\
\text { Kebugaran }\end{array}$ & 2019 \\
\hline 33 & Jurnal & $\begin{array}{l}\text { Aplikasi Monitoring Perkembangan Janin } \\
\text { (Antenatal Care) dengan Metode Scrum } \\
\text { Berbasis Perangkat Mobile [50] }\end{array}$ & SCRUM & Kedokteran & 2019 \\
\hline 34 & Jurnal & $\begin{array}{l}\text { Perancangan Aplikasi Edukasi Resep } \\
\text { Masakan Modern Berbasis Android dengan } \\
\text { Metode Extreme Programming [51] }\end{array}$ & $\mathrm{XP}$ & $\begin{array}{l}\text { Makanan \& } \\
\text { Minuman }\end{array}$ & 2019 \\
\hline 35 & Prosiding & $\begin{array}{l}\text { Rancang Bangun Sistem Integrasi Angkutan } \\
\text { Kota (Siangkot) Guna Mendukung Program } \\
\text { Jaklingko [52] }\end{array}$ & XP & Bisnis & 2019 \\
\hline 36 & Jurnal & $\begin{array}{l}\text { Rancang Bangun Sistem Informasi } \\
\text { Kesehatan Bayi dan Balita Berbasis Android } \\
{[53]}\end{array}$ & $\mathrm{AM}$ & Kedokteran & 2019 \\
\hline 37 & Jurnal & $\begin{array}{l}\text { Pembangunan Sistem Informasi Praktik } \\
\text { Pengalaman Lapangan (PPL) Berbasis } \\
\text { Android (Studi Pada Fakultas Ilmu Komputer } \\
\text { Universitas Brawijaya) [54] }\end{array}$ & XP & Produktivitas & 2019 \\
\hline 38 & Jurnal & $\begin{array}{l}\text { Perancangan Aplikasi Absensi Online } \\
\text { dengan Menggunakan Bahasa Pemrograman } \\
\text { Kotlin [55] }\end{array}$ & $\mathrm{AM}$ & Produktivitas & 2020 \\
\hline 39 & Jurnal & $\begin{array}{l}\text { Rancang Bangun Aplikasi Kamus Bahasa } \\
\text { dan Aksara Lampung Dialek A dan Dialek O } \\
\text { Berbasis Android [56] }\end{array}$ & $\mathrm{AM}$ & 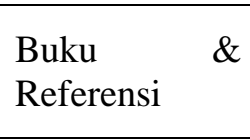 & 2020 \\
\hline 40 & Jurnal & $\begin{array}{l}\text { Revamp Aplikasi Teman Bumil Lebih } \\
\text { Interaktif dengan Pendekatan Agile [57] }\end{array}$ & SCRUM & Kedokteran & 2020 \\
\hline 41 & Jurnal & $\begin{array}{l}\text { Sistem Notifikasi Tugas Akhir Universitas } \\
\text { Bina Darma Berbasis Mobile [58] }\end{array}$ & $\begin{array}{l}\text { Mobile } \\
\text { D }\end{array}$ & Pendidikan & 2020 \\
\hline 42 & Prosiding & $\begin{array}{l}\text { Rancang Bangun Aplikasi Pembelajaran } \\
\text { Mahfudzot Untuk Pondok Pesantren Berbasis } \\
\text { Android Menggunakan Metode Extreme } \\
\text { Programming [59] }\end{array}$ & XP & Pendidikan & 2020 \\
\hline 43 & Jurnal & $\begin{array}{l}\text { Software Development dengan Extreme } \\
\text { Programming (XP) Pada Aplikasi Deteksi } \\
\text { Kemiripan Judul Skripsi Berbasis Android } \\
{[60]}\end{array}$ & XP & Pendidikan & 2020 \\
\hline 44 & Jurnal & $\begin{array}{l}\text { Sistem Pendeteksi Ketinggian Air } \\
\text { Menggunakan Internet of Things Berbasis } \\
\text { Android untuk Memberikan Informasi Data } \\
\text { Ketinggian Air Melalui Notifikasi Email [61] }\end{array}$ & XP & Cuaca & 2020 \\
\hline
\end{tabular}


b. Result Reporting RQ 1

RQ1 berfokus pada tren model apa saja yang digunakan dalam mengimplementasikan metode agile. Untuk menjawab RQ1 dengan menggunakan 44 literatur yang dipilih.

c. Result Reporting RQ 2

RQ2 berfokus pada bidang apa saja yang digunakan mengimplementasikan metode agile dalam pengembangan aplikasi berbasis mobile. RQ2 dengan menggunakan 44 literatur yang dipilih.

\section{Hasil dan Pembahasan}

1. RQ1: Tren model apa saja yang digunakan dalam metode agile?

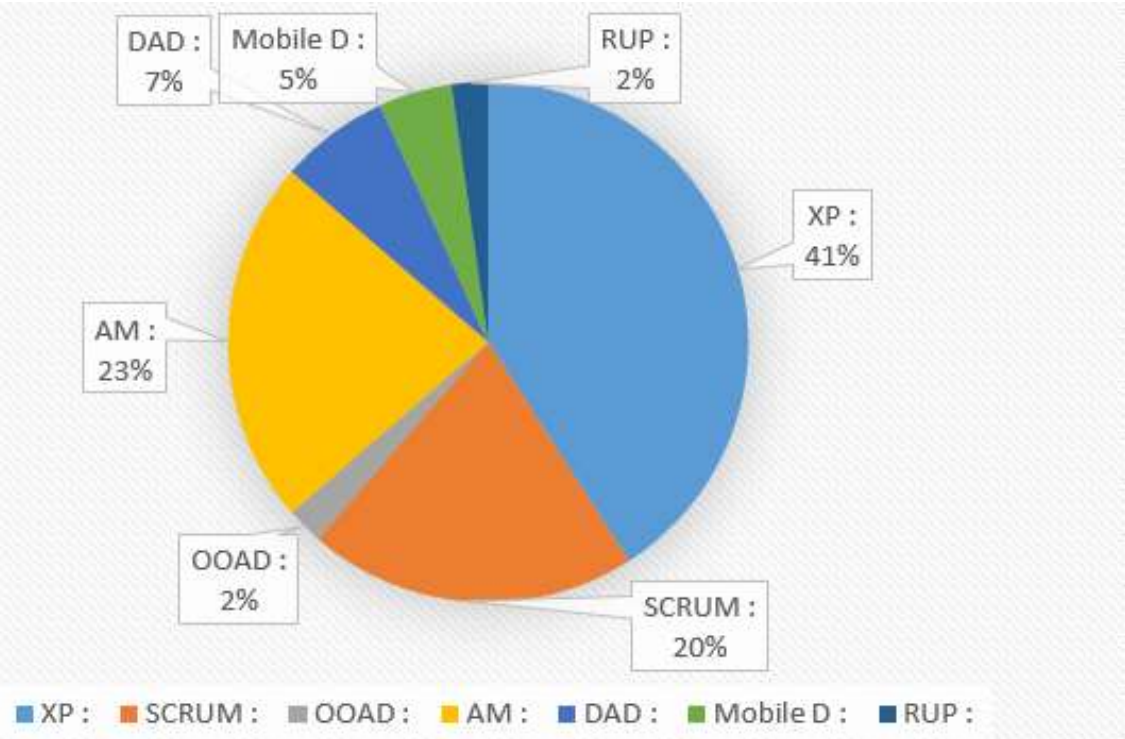

Gambar 3. Grafik Tren Model yang Biasa digunakan dalam Metode Agile

Terdapat banyak model yang bisa digunakan di dalam metode agile. Berdasarkan 44 literatur peneliti menemukan tujuh model yaitu: (1) Extreme Programming (XP) seperti pada literatur [21], [24]. [29], [30], [33], [34], [35], [36], [37], [38], [39], [40], [51], [52], [54], [59], [60], [61]. (2) Agile Modelling (AM) seperti pada literatur [20], [41], [42], [44], [47], [48], [3], [53] , [55], [56]. (3) SCRUM seperti pada literatur [22], [25], [26], [43], [46], [14], [49], [50], [57]. (4) Disciplined Agile Delivery (DAD) seperti pada literatur [27], [28], [45]. (5) Mobile D seperti pada literatur [32], [58]. (6) Object Oriented Agile Development (OOAD) seperti pada literatur [23], dan (7) Rational Unified Process (RUP) seperti pada literatur [31]. Pada Gambar 3, model yang paling banyak digunakan adalah model XP dengan persentase $41 \%$, sedangkan model yang paling sedikit digunakan adalah model OOAD dan RUP dengan persentase 2\%. Model lain yaitu AM, Model SCRUM, DAD dan Mobile D secara simultan memiliki persentase 23\%, 20\%, 7\%, dan 5\%.

Model XP menjadi model yang paling banyak digunakan karena memiliki keunggulan seperti: (1) Memudahkan manajer proyek dalam menjalin komunikasi yang baik dengan klien. (2) Menurunkan biaya pengembangan dalam pengimplementasian sistem. (3) Meningkatkan komunikasi dan sifat saling menghargai antar developer. (4) XP merupakan metodologi yang semiformal yang berarti developer harus selalu siap dengan perubahan atau dengan kata lain fleksibel [36]. 
2. RQ2: Bidang apa saja yang mengimplementasikan metode agile dalam pengembangan aplikasi berbasis mobile?

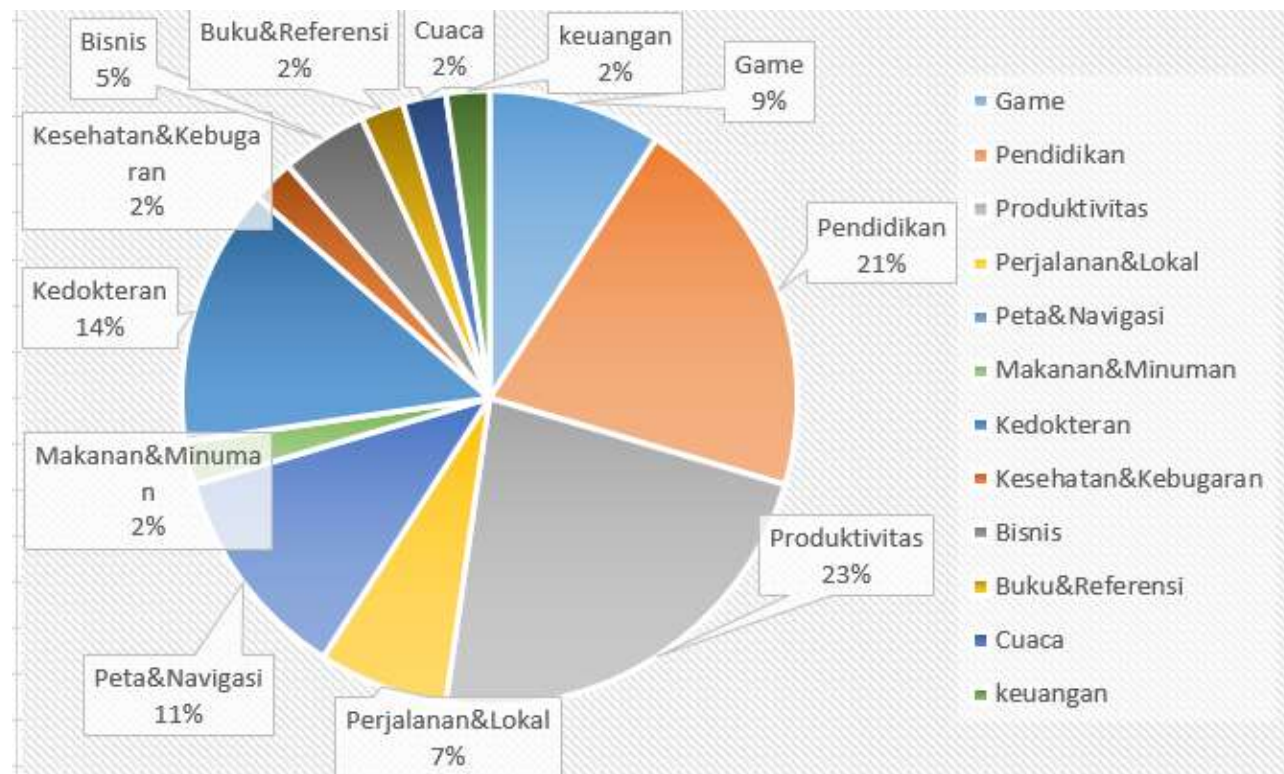

\section{Gambar 4. Grafik Bidang Dalam Pengembangan Aplikasi Mobile Dengan Metode Agile}

Peneliti menemukan 12 fokus bidang dalam pengembangan aplikasi mobile dengan menggunakan metode agile seperti pada Gambar 4 yaitu: (1) Produktivitas seperti pada literatur [22], [25], [28], [29], [32], [34], [37], [41], [54], [55]. (2) Pendidikan seperti pada literatur [21], [31], [35], [43], [48], [3], [58], [59], [60]. (3) Kedokteran seperti pada literatur [30], [38], [40], [50], [53], [57]. (4) Peta \& Navigasi seperti pada literatur [23], [24], [36], [42], [45]. (5) Game seperti pada literatur [20], [26], [33], [39]. (6) Perjalanan \& Lokal seperti pada literatur [27], [44], [47]. (7) Bisnis seperti pada literatur [46], [52]. (8) Makanan \& Minuman seperti pada literatur [51]. (9) Kesehatan \& Kebugaran seperti pada literatur [49]. (10) Buku \& Referensi seperti pada literatur [56]. (11) Cuaca seperti pada literatur [61] dan (12) Keuangan seperti pada literatur [14]. Pengembangan aplikasi berbasis mobile dengan metode agile didominasi oleh bidang produktivitas dengan persentase 23\%, dan yang paling sedikit yaitu bidang makanan \& minuman, kesehatan \& kebugaran, buku \& referensi, cuaca dan keuangan dengan persentase masing-masing yaitu 2\%. Bidang lain yaitu pendidikan, kedokteran, peta \& navigasi, game, perjalanan \& lokal dan bisnis yang secara simultan memiliki persentase $21 \%, 14 \%, 11 \%, 9 \%, 7 \%$, dan $5 \%$.

Fokus bidang yang paling sering digunakan dalam penelitian adalah bidang produktivitas untuk mendukung pekerjaan agar lebih produktif.

\section{Kesimpulan}

Berkembangnya smartphone yang cepat dan semakin canggih memberi dampak meningkatnya aplikasi berbasis mobile. Penelitian ini meninjau literatur penggunaan metode agile dalam pengembangan aplikasi berbasis mobile. Literatur yang ditinjau sebanyak 44 literatur. Metode agile memiliki banyak model. Dari 44 literatur, ditemukan bahwa model yang paling sering digunakan di dalam pengembangan aplikasi berbasis mobile adalah model Extreme Programming (XP) dengan persentase $41 \%$ dan yang paling sedikit digunakan adalah model Object Oriented Agile Development (OOAD) dan Rational Unified Process (RUP) dengan persentase masing-masing 2\%. Sedangkan fokus bidang yang paling banyak dijadikan tema penelitian adalah di bidang produktivitas dengan persentase $23 \%$ dan yang paling sedikit dijadikan tema penelitian adalah bidang bidang makanan \& minuman, kesehatan \& kebugaran, buku \& referensi, cuaca dan keuangan dengan persentase masingmasing yaitu $2 \%$. 


\section{Referensi}

[1] B. Kitchenham, "Procedures for Performing Systematic Reviews," P. 33.

[2] W. Ten Ham-Baloyi and P. Jordan, "Systematic Review as A Research Method in Post-Graduate Nursing Education," Health Sa Gesondheid, Vol. 21, Pp. 120-128, Dec. 2016, Doi: 10.1016/J.Hsag.2015.08.002.

[3] D. A. Puspa Putri, "Rancang Bangun Media Pembelajaran Bahasa Arab Untuk Anak Usia Dini Berbasis Android," Technol. J. Ilm., Vol. 10, No. 3, P. 156, Jul. 2019, Doi: 10.31602/Tji.V10i3.2230.

[4] Malik. R. F, Fachrurrozi. M, Prabowo, R. "Sistem Informasi Manajemen Laboratorium Menggunakan Metode Agile Dengan Konsep Model-View-Controller Data Access Object" P. 6569.

[5] A. Kaur, "Review On Agile Approach to Mobile Application Development," Vol. 3, No. 4, P. 4, 2016.

[6] K. W. Tracy, "Mobile Application Development Experiences On Apple's Ios and Android Os," Ieee Potentials, Vol. 31, No. 4, Pp. 30-34, Jul. 2012, Doi: 10.1109/Mpot.2011.2182571.

[7] R. Vallon, B. J. Da Silva Estácio, R. Prikladnicki, And T. Grechenig, "Systematic Literature Review On Agile Practices in Global Software Development," Inf. Softw. Technol., Vol. 96, Pp. 161-180, Apr. 2018, Doi: 10.1016/J.Infsof.2017.12.004.

[8] C. Wu and D. Barnes, "A Literature Review of Decision-Making Models and Approaches for Partner Selection in Agile Supply Chains," J. Purch. Supply Manag., Vol. 17, No. 4, Pp. 256-274, Dec. 2011, Doi: 10.1016/J.Pursup.2011.09.002.

[9] G. Ramesh and S. R. Devadasan, "Literature Review On the Agile Manufacturing Criteria," J. Manuf. Technol. Manag., Vol. 18, No. 2, Pp. 182-201, Feb. 2007, Doi: 10.1108/17410380710722890.

[10]A. S. Campanelli And F. S. Parreiras, "Agile Methods Tailoring - A Systematic Literature Review,” J. Syst. Softw., Vol. 110, Pp. 85-100, Dec. 2015, Doi: 10.1016/J.Jss.2015.08.035.

[11]I. Inayat, S. S. Salim, S. Marczak, M. Daneva, And S. Shamshirband, "A Systematic Literature Review On Agile Requirements Engineering Practices and Challenges," Comput. Hum. Behav., Vol. 51, Pp. 915-929, Oct. 2015, Doi: 10.1016/J.Chb.2014.10.046.

[12]N. Ibrahim, "An Overview of Agile Software Development Methodology and Its Relevance To Software Engineering," Vol. 2, No. 1, P. 18, 2007.

[13]I. Carolina, A. M. H. Pardede, And A. Supriyatna, "Penerapan Metode Extreme Programming Dalam Perancangan Aplikasi Perhitungan Kuota Sks Mengajar Dosen," Ina-Rxiv, Preprint, Feb. 2019. Doi: $10.31227 /$ Osf.Io/Se6f9.

[14]J. Arka, A. H. Brata, And K. C. Brata, "Pengembangan Aplikasi Mobile Manajemen Keuangan Dengan Metode Scrum (Studi Kasus Mahasiswa Filkom Ub)," P. 9.

[15]Boehm. B.W, "A Spiral Model of Software Development and Enhancement", p.61-72, 1988.

[16]R. Ilyas and Y. H. Chisnanto, "Pengembangan Sistem Informasi Penelitian Lppm Universitas Jenderal Achmad Yani Dengan Agile Sdlc," P. 6, 2018.

[17]A. Y. Ranius and A. Muzakir, "Implementasi Metode Mobile-D Untuk Pembuatan Ensiklopedia Kebudayaan Kota Palembang Berbasis Android," P. 12.

[18]Google, "Choose A Category and Tags for Your App or Game," Apr. 04, 2021. Https://Support.Google.Com/Googleplay/Android-

Developer/Answer/9859673?Hl=Id\#Zippy=\%2capps\%2cgames\%2caplikasi\%2cgame.

[19]K. Ba and S. Charters, "Guidelines for Performing Systematic Literature Reviews In Software Engineering," Vol. 2, Jan. 2007.

[20]Simamora. R. T. W. P, Kurniawati. A, Puspitasari. W, "Membangun Mobile Game Sebagai Assistive Technology Untuk Membantu Mengembangkan Social Interaction Skill Pada Penderita Attention Deficit Hyperactivity Disorder (ADHD) Menggunakan Metode Agile Development", P. 44-51, 2017.

[21]R. Anjuliani and L. W. Astuti, "Aplikasi Isc (Informatics Student Center) Menggunakan Metode Personal Extreme Programming Berbasis Android,” Vol. 6, P. 6, 2015. 
[22]P. Utomo and F. W. Prayitno, "Perancangan Dashboard Sistem Informasi Untuk Agile Manajemen Proyek Dengan Menggunakan Jira - Studi Kasus Di Pt. Flashiz Indonesia," Vol. 5, No. 2, P. 8.

[23]C. Ammar and H. Suprapto, "Penerapan Algoritma Floyd Warshall Dalam Pencarian Rute Terpendek Dan Tercepat Pada Studi Kasus Di Singapura Hingga Thailand Selatan Berbasis Android," Vol. 20, No. 2, P. 16, 2015.

[24]F. Adikara, "Pemanfaatan Mac Address Hostspot Dalam Pengembangan Sistem Absensi Gps Dalam Rangka Meningkatkan Keakuratan Posisi Pengguna," Sisfo, Vol. 05, No. 04, Sep. 2015, Doi: 10.24089/J.Sisfo.2015.09.007.

[25] Ardiansyah, Fendina. G. P. Putri, "Pengembangan Sistem Manajemen Presensi Rapat Berbasis Qr Code Pada Android", p. 51-56.

[26]A. Herdiana, "Pengembangan Game 'Super Sonic Shoot' Dengan Pendekatan Game-Scrum," P. 6.

[27]N. E. Christian, Y. D. Y. Rindengan, And P. D. K. Manembu, "Rancang Bangun Aplikasi Fasilitas Umum Berbasis," Vol. 8, No. 1, P. 5, 2016.

[28]H. Koyuko, A. A. E. Sinsuw, And X. B. N. Najoan, "Perancangan Aplikasi Monitoring Pemadaman Listrik Berbasis Android Studi Kasus PT. PLN Area Manado," Vol. 8, No. 1, P. 11.

[29]F. Adikara and Teknik Informatika, Fakultas Ilmu Komputer, Universitas Esa Unggul, "Pengembangan Fungsi Pengajuan Cuti Karyawan Pada Sistem Absensi Mobile," Sisfo, Vol. 06, No. 01, Pp. 77-88, Sep. 2016, Doi: 10.24089/J.Sisfo.2016.09.006.

[30]C. R. Pasalli, V. C. Poekoel, And X. Najoan, "Sistem Pakar Diagnosa Penyakit Anak Menggunakan Metode Forward Chaining Berbasis Mobile," P. 6, 2016.

[31]Sugara. E. P. A, Perdana.A, Subrata. A, "Aplikasi Pembelajaran Sejarah Filsafat Berbasis Android Menggunakan Metode Pengembangan Agile", Seminar Nasional Teknologi Informasi, p. 51-56.

[32]U. Ependi, "Mobile Application Monitoring Pengisian Uang Anjungan Tunai Mandiri Pt Bank Mandiri Cabang Palembang," J. Edukasi Dan Penelit. Inform. Jepin, Vol. 3, No. 1, P. 33, May 2017, Doi: 10.26418/Jp.V3i1.20115.

[33]Y. B. Wijaya and W. Utomo, "Rancang Bangun Game Edukasi Anak Usia Dini Menggunakan Metode Extreme Programming Berbasis Android," Vol. 1, P. 11, 2017.

[34]G. Syarifudin and I. D. A. E. Yuliani, "Pemanfaatan Jquery Mobile Untuk Merancang Aplikasi Kinerja Salesman,” Sisfotenika, Vol. 7, No. 1, Jan. 2017, Doi: 10.30700/Jst.V7i1.136.

[35]F. T. S. Butarbutar, T. H. Kusmanto, And A. Irawan, "Rekayasa Perangkat Lunak Berbasis Android Sebagai Media Informasi Akademik Siswa Smk Pkp 2 Jakarta,” No. 3, P. 7, 2017.

[36]Y. I. Chandra, "Perancangan Aplikasi Navigasi Peta Dengan Pengenalan Suara Menggunakan Pendekatan Agile Process Dengan Model Extreme Programming Berbasis Android," Vol. 1, No. 2, P. 10, 2017.

[37]T. Astuti, G. Kusumastuti, And R. Fitriyanto, "Pemanfaatan Analytical Hierarchy Process (Ahp) Pada E-Voting Pemilihan Ketua Osis," P. 10.

[38]M. T. Pallangan, V. C. Poekoel, And A. Sambul, "Sistem Pakar Diagnosa Autisme Pada Balita Berbasis Android," J. Tek. Inform., Vol. 10, No. 1, Apr. 2017, Doi: 10.35793/Jti.10.1.2017.15804.

[39]L. G. Lamonge, X. N. B. Najoan, And B. A. Sugiarso, "Rancang Bangun Aplikasi Game Augmented Reality Permainan Tradisional Sulawesi Utara Dodorobe,” Vol. 12, P. 7, 2017.

[40]R. Bahana, R. Kosala, And Y. Heryadi, "Aplikasi Informasi Kesehatan Dan Diagnosa Penyakit Jantung Berbasis Android," P. 7, 2018.

[41]B. A. Nugroho and F. S. Efendi, "Pengembangan Aplikasi Android Berbasis Teknologi Cloud Computing Dan Qr Code Untuk Pendataan Bus Dan Penumpang Di Terminal Tipe-A Tamanan Kota Kediri," P. 10, 2018.

[42]Y. A. Susetyo, P. O. N. Saian, And R. Somya, "Pembangunan Sistem Informasi Zona Potensi Sumber Daya Kelautan Kabupaten Gunungkidul Berbasis Hmvc Menggunakan Google Maps Api Dan Json," P. 7, 2018.

[43]"Pembangunan Sistem Aplikasi Hanasu: Pembelajaran Bahasa Jepang Android Mobile Memanfaatkan Google Speech Recognition Library,” P. 8. 
[44]K. C. Brata and A. H. Brata, "Pengembangan Aplikasi Mobile Augmented Reality Untuk Mendukung Pengenalan Koleksi Museum,” J. Teknol. Inf. Dan Ilmu Komput., Vol. 5, No. 3, P. 347, Aug. 2018, Doi: 10.25126/Jtiik.201853798.

[45]A. N. Lomboan, D. J. Mamahit, And Y. D. Y. Rindengan, "Rancang Bangun Aplikasi Pencarian Rumah Ibadah Di Kotamobagu Berbasis Android," J. Tek. Inform., Vol. 13, No. 2, Aug. 2018, Doi: 10.35793/Jti.13.2.2018.22552.

[46]C. E. Prastio and N. Ani, "Aplikasi Self Service Menu Menggunakan Metode Scrum Berbasis Android (Case Study: Warkobar Café Cikarang)," Vol. 11, No. 2, P. 18, 2018.

[47]T. W. Widyaningsih, "Membangun Aplikasi Pariwisata Berbasis Android Di Belitung," P. 12.

[48]J. Sanjaya, E. Renata, V. E. Budiman, F. Anderson, And M. Ayub, "Integrasi Micro-Apps Individual Menjadi One-Stop Services Maranatha Application Suite," J. Tek. Inform. Dan Sist. Inf., Vol. 5, No. 3, Jan. 2020, Doi: 10.28932/Jutisi.V5i3.1993.

[49]M. A. Pratama, A. P. Kharisma, And A. H. Brata, "Pengembangan Aplikasi Sportyway: Aplikasi Pencari Teman Untuk Berolahraga Bersama Berbasis Lokasi," P. 7.

[50]Z. Imaduddin, H. Saptono, S. T. Fauziah, H. A. Tawakal, And D. Hamzah, "Aplikasi Monitoring Perkembangan Janin (Antenatal Care) Dengan Metode Scrum Berbasis Perangkat Mobile," Vol. 5, No. 1, P. 8, 2019.

[51]S. Utomo and K. P. Hilmadewi, "Perancangan Aplikasi Edukasi Resep Masakan Modern Berbasis Android Dengan Metode Extreme Programming," No. 2, P. 21, 2019.

[52]A. B. Aji, M. Hidayah, And N. Haski, "Rancang Bangun Sistem Integrasi Angkutan Kota (Siangkot) Guna Mendukung Program Jaklingko," P. 9, 2019.

[53]A. Chusyairi and P. R. N. Saputra, "Rancang Bangun Sistem Informasi Kesehatan Bayi Dan Balita Berbasis Android," P. 6, 2019.

[54]R. W. Setiawan, S. A. Wicaksono, And A. D. Herlambang, "Pembangunan Sistem Informasi Praktik Pengalaman Lapangan (Ppl) Berbasis Android (Studi Pada Fakultas Ilmu Komputer Universitas Brawijaya)," P. 10.

[55]A. Febriandirza, "Perancangan Aplikasi Absensi Online Dengan Menggunakan Bahasa Pemrograman Kotlin," P. 11, 2020.

[56]M. F. Azima and S. N. Laila, "Rancang Bangun Aplikasi Kamus Bahasa Dan Aksara Lampung Dialek A Dan Dialek O Berbasis Android," Vol. 14, No. 01, P. 9.

[57]E. Julianto and Y. Harjoseputro, "Revamp Aplikasi Teman Bumil Lebih Interaktif Dengan Pendekatan Agile," Vol. 4, No. 5, P. 7, 2020.

[58]R. Andri, N. A. O. Saputri, And M. Akbar, "Sistem Notifikasi Tugas Akhir Universitas Bina Darma Berbasis Mobile," J. Sist. Inf., Vol. 9, No. 1, P. 11, 2020.

[59]W. Bismi and T. Asra, "Rancang Bangun Aplikasi Pembelajaran Mahfudzot Untuk Pondok Pesantren Berbasis Android Menggunakan Metode Extreme Programming," P. 7, 2020.

[60]I. Ahmad, R. I. Borman, J. Fakhrurozi, And G. G. Caksana, "Software Development Dengan Extreme Programming (Xp) Pada Aplikasi Deteksi Kemiripan Judul Skripsi Berbasis Android," Vol. 5, No. 2, P. 11, 2020.

[61]L. Listiyoko, A. Fahrudin, And A. A. Saputra, "Sistem Pendeteksi Ketinggian Air Menggunakan Internet of Things Berbasis Android Untuk Memberikan Informasi Data Ketinggian Air Melalui Notifikasi Email," Vol. 15, No. 1, P. 14. 